\title{
Didactic Strategies and Competencies of Gifted Students in the Digital Era
}

Grozdanka GoJKOV*1, AleKsandar StOJANOVIĆ ${ }^{\star}$, AND

Aleksandra Gojkov-Rajić 3

$\approx \quad$ This paper presents the findings of explorative research undertaken on an intentional sample consisting of 112 master's students of pedagogy in Serbia, assumed to be potentially gifted and to have demonstrated academic giftedness, since their average mark during their studies was above 9.0o on a scale of 1.o to 10.0. The intention was to examine the influence of didactic strategies and methods on the competencies of gifted students and thus verify the hypothesis on the significance of certain didactic strategies and methods for the contribution of higher education teaching in order to encourage intellectual autonomy in learning in the case of gifted university students. The method of systematic non-experimental observation was used, accompanied by an assessment scale used by students to estimate the level of the presence of the listed strategies, methods or procedures during studies and to what an extent learning and teaching strategies used in lectures, exercises, seminars, and consultations addressed their needs and contributed to the development of competencies. When making a choice between didactic strategies, methods and procedures, particular attention was paid to the 52 offered methods in order to include 30 of those that refer to problem learning, creative approaches to learning, critical autonomy etc., and for the list of 35 competencies of which 30 refer to independent thinking and are elements of critical thinking and indicators of, above all, approaches to the learning of gifted students. The essential finding was that the achieved competencies with higher average values were, mostly, those that are important for intellectual functioning, but that were not directly connected to what explains critical thinking, intellectual autonomy, as well as to the knowledge of basic concepts, the understanding of facts, and the giving explanations of events.

Keywords: gifted students, intellectual autonomy, didactic strategies and methods, digital era

$1 \quad{ }^{\star}$ Corresponding Author. Teacher Education Faculty, University of Belgrade, and Preschool Teacher Training College "Mihailo Palov" Vršac, Serbia; g_gojkov@open.telekom.rs

2 Teacher Education Faculty, University of Belgrade, and Preschool Teacher Training College "Mihailo Palov" Vršac, Serbia

3 Teacher Education Faculty, University of Belgrade, and Preschool Teacher Training College

"Mihailo Palov" Vršac, Serbia 


\section{Didaktične strategije in kompetence nadarjenih študentov $\mathrm{v}$ digitalni dobi}

Grozdanka GojKov*, Aleksandar Stojanović, AND

Aleksandra GojKov-Rajić

$\propto$ V prispevku so predstavljeni rezultati eksplorativne raziskave, ki je bila izvedena na namenskem vzorcu 112 magistrskih študentov pedagogike $\mathrm{v}$ Srbiji. Za vse so predvidevali, da so potencialno nadarjeni in da izražajo akademsko nadarjenost, saj je bila povprečna ocena njihovega študija nad 9,00 na lestvici od 1,0 do 10,0. Namen raziskave je bil ugotoviti, kak vpliv imajo didaktične strategije in metode na kompetence nadarjenih študentov. Tako bi potrditi hipotezo o pomembnosti določenih didaktičnih strategij in metod visokošolskega poučevanja $\mathrm{k}$ spodbujanju intelektualne avtonomije $\mathrm{v}$ procesu učenja pri nadarjenih študentih. Podatki so bili zbrani s sistematičnim neeksperimentalnim opazovanjem in z ocenjevalno lestvico. Študentje so ocenili stopnjo prisotnosti navedenih strategij, metod ali postopkov med študijem in v kolikšni meri strategije, ki so uporabljene na predavanjih, vajah, seminarjih, na konzultacijah, zadovoljujejo njihove potrebe ter prispevajo k razvijanju kompetenc. Ko so izbirali med didaktičnimi strategijami, metodami in postopki, je bila posebna pozornost namenjena 52 metodam, izmed katerih jih je 30 vključevalo problemsko zasnovano učenje, ustvarjalne pristope $\mathrm{k}$ učenju, kritično avtonomijo itn. Na seznamu 35 kompetenc pa je bilo 30 takih, ki so vključevali samostojno razmišljanje, elemente kritičnega razmišljanja in so predvsem kazalniki pristopov učenja nadarjenih študentov. Temeljna ugotovitev raziskave je, da so kompetence, kjer študentje dosegajo višje povprečne rezultate, večinoma tiste, ki so pomembne za intelektualno funkcioniranje, a niso neposredno povezane s kritičnim razmišljanjem, $\mathrm{z}$ intelektualno avtonomijo niti znanjem osnovnih konceptov, razumevanjem dejstev in s pojasnjevanjem dogodkov.

Ključne besede: nadarjeni študentje, intelektualna avtonomija, didaktične strategije in metode, digitalna doba 


\section{Introduction}

The digital age and changes in the field of higher education, which are conditioned by factors such as knowledge expansion, new technologies, new forms of communication etc., are accepted only partially, from the perspective of the gifted. They are the most prominent in the areas of new content selection, the structuring of educational plans and programs, especially with didactic material. The ability of this material to handle new changes in society is continually decreasing on a global level and, therefore, also in regard to gifted children. The entire educational system will expand and grow, the length of education will be increased, the importance of general education will continually increase, and a growing number of people will join this sector because even today individuals are expected to be able to perform a wide range of unforeseen tasks, and this requires the development of key abilities, including analytical thinking, team work, independence, self-initiative, which is followed by expertise and other personal competencies. From the gifted point of view this means, there is a need to view the ideal of critical thinking from the perspective of the "American Philosophical Formulation", which Facione (1990) gives in his Delphi-study. There he shifts the focus from critical thinking as a process to the critical thinker as a person, i.e. the need for the development of the critical thinker, who is curious, well informed, open minded, flexible, who challenges his/her reason, is honest in thinking and evaluation, is honest in the confrontation with personal prejudices, is cautious when making decisions, ready to rethink and reconsider, clear in forming questions, organized in complex matters, diligent in the search for relevant information, responsible for the grouping of criteria, focused on the task, and persistent in the search for solutions that are as precise as the subject and the conditions which enable the research.

In the higher education teaching, student participation, codetermination, research and interdisciplinarity as elements of emancipated studies have long been insisted upon. Therefore, higher education institutions are searching for adequate forms and types of classes and research methods or, (in other words) student guidelines, towards efficient self-learning in which the dominant effect is intellectual autonomy. If this is viewed from the gifted perspective, then it is even more important to take into consideration the possibilities that the digital age gives to the development of the intellectual autonomy of gifted students. Our research results (Gojkov, 2013; Gojkov \& Stojanovic, 2012), i.e. the empirical tests of the reach and limitations of the application of innovative potentials of contemporary models in the higher education teaching (project method, discourse method and didactic instructions which convene 
with the dimensions of the cognitive style, etc.) from the perspective of the encouragement of gifted students' metacognitive abilities and intellectual autonomy, point to the conclusion that gifted students' metacognitive approach to learning is connected to the ICT technology in the process of self-study and research. This is especially evident in the application of the project method and discourse method, which are easily combined with the classic system of teaching. Students' evaluation of this method of education is positive, while the motivation for participating in projects is intrinsic. Acquiring knowledge through the project and discourse method are considered more interesting and efficient than through the classic academic presentations, usually because students can research, independently find information by networking with students around the globe, consulting with each other on information sources, etc. (Gojkov, 2013; Gojkov \& Stojanovic, 2012). Students today efficiently use English, German, and other languages and thus overcome spatial barriers, they access libraries around the world, communicate with students and others who share the same interests, and therefore learn with far more motivation, and manifest high levels of flexibility, creativity, risk-taking and persistence in the search for argumentation which supports their ideas. In this manner, the importance of ICT technologies contributes to the development of the intellectual autonomy of gifted students, because they have the opportunity to prepare for discussions, which occur during lectures, practical classes, and seminars, and thus develop new arguments from different angles of the posed question, or a question that they themselves ask. Therefore, borders are erased, and participation epistemology in the learning approach is enabled, which in turn opens the road to autonomous and self-regulated learning. In other words, a well-known pedagogic maxim was enabled: If you want to be free, educate yourself. The gifted know this well and use it. The world is theirs and, thanks to digital technology, many things are already in the palm of their hands.

\section{Theoretical approach to the problem}

Critical thinking in pedagogy and higher education didactic concepts of education of the gifted are rooted in pedagogy; therefore, in higher education, didactics are rooted in emancipated epistemology. It is based on the views of authors such as Paul-Elder, who states:

Critical thinking is a way of thinking (valid for all subjects, content or problems), in which a person strengthens their thinking quality, by challenging themselves to follow the inherent structures of thinking and to measure them through intellectual norms (as cited in Kruse, 2010, p. 76). 
In emancipated didactics, "critical thinking" refers to the aspects of selfgovernment and self-reflection in thinking, which are dependent on following intellectual norms. Critical thinking in didactics is conscious thinking for which the aforementioned authors state:

Critical thinking in short means: self-governed, self-disciplined, selforganized and self-correcting thinking, which implies strict quality criteria, leads to active communication and problem-solving capability and constant obligation to suppress innate egoism and group-egoism." (Paul-Elder, as cited in Kruse, 2010, p. 124).

Paul-Elder also underscored the importance of quality measurement. They contribute to the definition of the term by adding social aspects such as "communication skills and the capability of finding problems", as well as the ability to be aware of their interest position and realize its influence on thinking. Contrary to the aforementioned views, they see critical thinking as independent of the domain and discipline in which it occurs. Today, this view is often criticized by Willingham (2007). The critical thinking ideal is formulated by the American Philosophical Association in their Delphi study, in which the focus is diverted from thinking as a process to the thinker as a person:

The ideal critical thinker is curious, well informed, open minded, flexible, who challenges his/her reason, is honest in thinking and evaluation, is honest in the confrontation with personal prejudices, is cautious when making decisions, ready to rethink, clear in forming questions, organized in complex matters, diligent in the search for relevant information, responsible in the grouping of criteria, focused on the task, and persistent in the search for solutions which are as precise as the subject and the conditions which enable the research (Facione, 1990, p. 65).

This is to be expected from the gifted and is most easily developed in them. In this study, there are two key elements of critical thinking singled out: cognitive competency and affective disposition, of which the former is attributed to the procedural side and the latter to the dispositional side of critical thinking. Experts are unsure whether they operate interdependently. With regards to critical thinking, a third of them wanted to strictly define the critical thinker as a person (Heyman, 2008). Everyone is in agreement that the procedural side is the determining one. If critical thinking is to be taught, it is the view of the authors of this text that that both aspects need to be addressed in unison; "Therefore, in good critical thinkers we talk about ideals. Development of critical thinking as a skill is combined with the nurturing of these dispositions which contribute to useful insights and are the basis of a rational democratic society" (Facione, 1990, p. 68). Critical thinking, therefore, according to 
this study, cannot be described only on the basis of actions (thinking, argumentation, receiving information), but it requires the person's competencies, opinions and approaches to thinking. This is a part of comprehensive schooling in a democratic society that is founded on rationality.

The aforementioned definitions indicate that critical thinking is not a simple one-dimensional concept. It is a collective concept of all of the attempts to make thinking more precise, to control it and validate it for mistakes, which arise from a person who consciously acts and thinks (Facione, 1990). Critical thinking is not only an academic but also a social requirement. It has cognitive, methodological, ethical and emotional associations. It cannot be developed separately from the character that uses it. Critical thinking is a broader concept than scientific thinking, even though both terms are used as synonyms in the scientific community. Critical thinking is above that and represents an important educational goal to be developed through an array of conscious influences on the thinking quality, independent decision-making, and rational behaviour. The introduction of critical thinking to curricula should be as early as elementary school (Kuhn, 2005, as cited in Gojkov, 2007).

In the digital age, the gifted have great opportunities for the development of intellectual autonomy, on which emancipated didactics insist, and for which there is ample support from the European qualification framework (www.jointquality.org, European Council, 2008), which legitimizes the curricula decided directedness towards the acquisition of critical thinking. Unfortunately, however, there is no guarantee that it will develop, because the didactic support that encourages the intellectual autonomy of the student is necessary for the nurturing of critical thinking. For the gifted, this means even more chances for the development of their intellect, creativity as well as character traits, which are a necessary framework for creativity and critical thinking. How does this look in the pedagogy studies at the Philosophical Faculty in Serbia, where professors know more about the didactic strategies, methods and procedures for the encouragement of intellectual autonomy than the professors from other faculties and where the students also study all of this as well as how to implement that knowledge in the practical work of the schools? This is the question that initiated the study, the results of which are partially represented in this paper in order to argue the view that the didactic strategy and method reached from the perspective of ICT technologies in the work with gifted children is still not sufficient, especially when considered from the perspective of contributions to intellectual autonomy, where they could actually be the most efficiently, the most rationally and the most economically used. 


\section{Methodology framework}

Represented in this paper are the results of an exploration research on a convenience sample of 112 students (98 women and 14 men) on their master's studies at the Faculty of Philosophy, majoring in pedagogy in Serbia, whose average grade is above 9.00 and who, therefore, are taken as potentially gifted and who have attained academic giftedness. The intention was to examine the influence of didactic strategies and methods on the competencies of gifted students, thus verifying the hypothesis of the positive effect of certain didactic strategies and methods in faculty classes on the encouragement of intellectual autonomy of learning in the case of the gifted. The research was carried out in 2013 and 2014. The students filled in a questionnaire. The first part consisting of Likert scale type statements, i.e. an assessment scale was used by students to estimate the level of presence of the enlisted strategies, methods or procedures during their studies and to what extent learning and teaching strategies were used in lectures, exercises, seminars. The second part of the instrument constructed for the purpose of the research (DSCGS-1 - Didactic strategies and competencies of gifted students) referred to the scale according to which students assessed their competencies regarding critical thinking as an expression of intellectual autonomy.

The method of systematic non-experimental observation was used as well as an assessment scale used by students to estimate the level of the presence of the enlisted strategies, methods or procedures during studies and to what an extent learning and teaching strategies used in lectures, exercises, seminars, consultations addressed their needs and contributed to competencies development. When making a choice between didactic strategies, methods and procedures, particular attention was paid to the 52 methods offered to include the 30 of them that refer to problem learning, creative approaches to learning, critical autonomy, use of ICT, etc., and for the list of 35 competencies to consist of the 30 of those that refer to independent thinking and that are elements of critical thinking and indicators of, above all else, an approach to the learning of gifted students. The data on the reliability of the instrument is high: Cronbach's Alpha is 0.975. From the component matrix of the factor analysis of the part of the instrument that refers to student competencies, it can be seen that seven factors were extracted, of which the first factor explains $68.644 \%$ of the variance. From the Pattern Matrix, it can be seen that after 25 iterations of convergence, significance is at 0.004 , which shows a significant mutual conformity of items in the instrument.

In the part of the instrument for monitoring of the application of the didactic processes in higher education teaching, 11 factors were extracted using the componential analysis method. From the matrix below, it can be seen that after 25 
iterations the convergence is significant at .01. From the communality table, it can be seen that the situation of certain items is from .6o or over .80 . The first factor explains $36.6 \%$ of the variance, and the total explained variance is $70.46 \%$, which significantly confirms the validity of this part of the instrument.

\section{Research findings and interpretation}

Out of the great number of data, the findings outline will include only those that most clearly and significantly indicate underlying issues of the research, i.e. the availability of didactic strategies and methods in higher education teaching (lectures, practical classes, seminars, consults, etc.) of gifted students. The first significant statement refers to the fact that none of the evaluated 60 strategies, methods and procedures completely fulfilled the expectations of gifted students; therefore, all are present but not to level expected. The same data can be seen in Table 1 Descriptive Statistics, as well as in the Chart 1 - The level of prominence of didactic strategies; they further prove that the following are insufficiently prominent and are not given sufficient attention: reshaping, brainstorming, forming new ideas, anticipating consequences, conceptualizing, writing reports after the implementation of instruments and Socratic method. Those are therefore methods and procedures with the lowest average grade, which spans between 2.17 to 2.93 (the minimal value is o, and the maximum is 5).

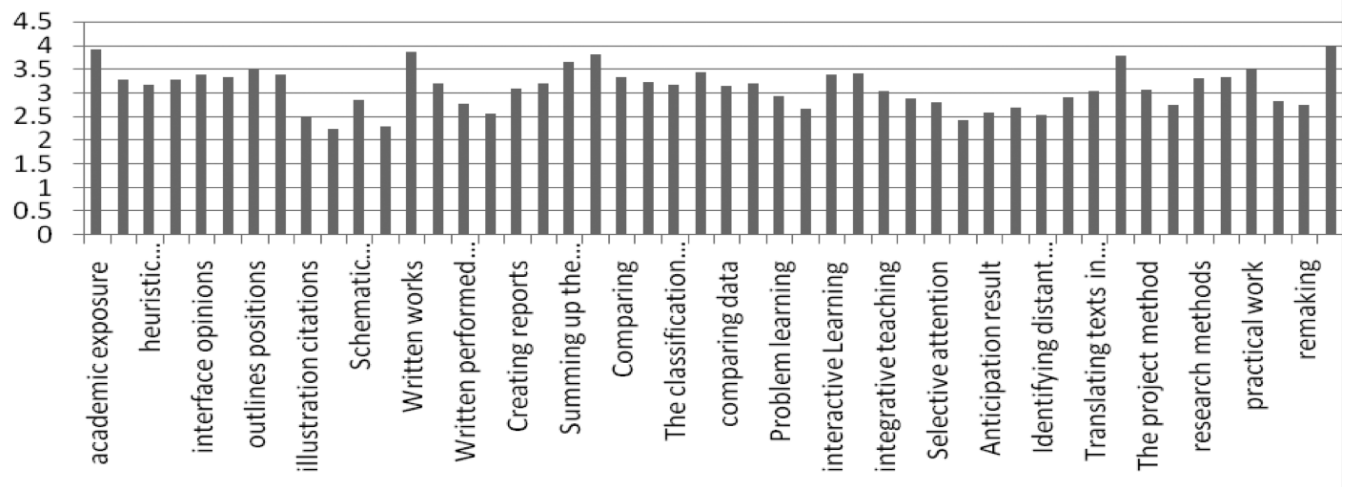

Chart 1. The degree of didactic strategy prominence

Unlike Chart 1, Chart 2, The level of needs for didactic strategies, shows that students express a strong need for the following methods and procedures: academic lecturing, evaluation, practical papers, research method, interpretation, forming of new ideas, founding of new procedures, self-reflective learning, 
brainstorming, comparison, interactive learning, self-organized learning, research learning, problem learning, data comparison, valuing of products, applying ideas, prominence of sceptical thinking, natural science thinking, prominence of networked thinking and prominence of self-reflective thinking, abstracting of ideas, raising questions, finding examples on the Internet and in the literature, essays, stating interesting details, explanation of attitudes, discussion on a topic, confrontation of opinions, discussion on predetermined problems.

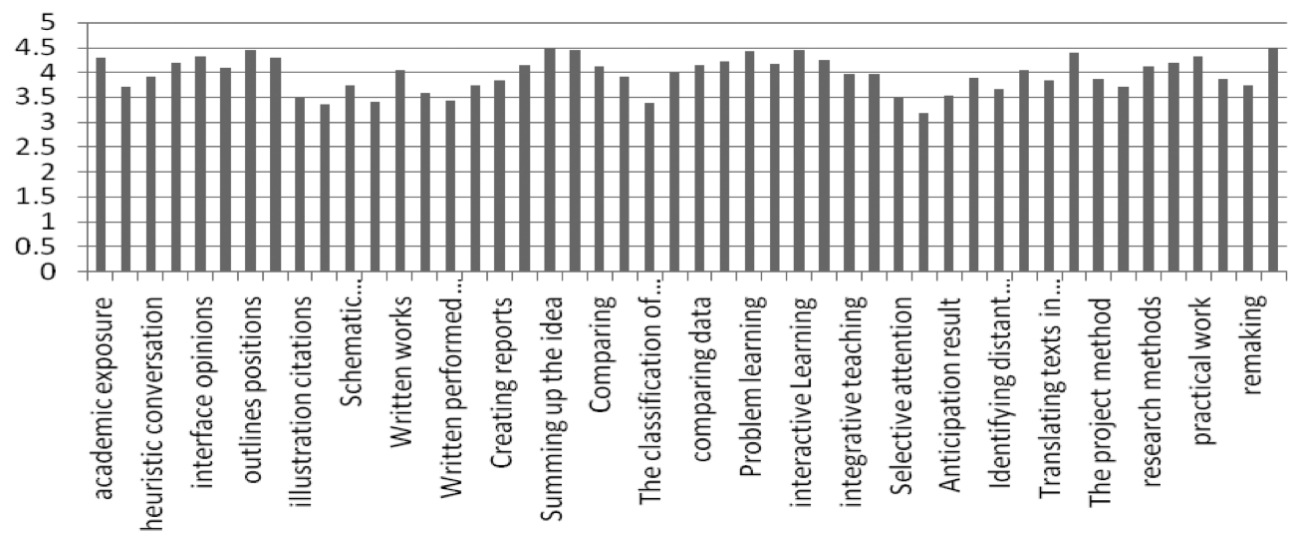

Chart 2. The level of needs for didactic strategies

Apart from the descriptive findings, the issue of self-evaluation of students on competencies achieved during studies is also significant. According to Table 1, Achieved competencies, and Chart 3, Realized competencies, it can be seen that students evaluate highly realized competences, mostly referring to the abilities of critical thinking, as well as others involved in the set of competencies implied by the notion of intellectual autonomy. It is evident that the ones stated as the weakest were: use of graphic data presentation, demonstration of the correct implementation of methods, demonstration of knowledge use, making an experiment plan, finding hidden connections between data, generalizing findings, product valuing, application of ideas, prominence of sceptical thinking, prominence of networked thinking, and prominence of self-reflected thinking. All these findings open the possibility that gifted students pay more attention than their professors to the question of autonomy, which (in the context of education), both in cognitive and behavioural sense means encouragement of expression of individual opinion, as well as possibility to apply competences involved in the notion of intellectual autonomy in research work. The 
aforementioned competencies are stated as being poorly developed, which underscores important elements of research thinking and strategies among which the following are singled out: experiment plan making, generalizing data, valuing products, idea application, prominence of sceptical thinking, natural science thinking, prominence of networked thinking and prominence of selfreflective thinking. Therefore, we could say that it is clear that gifted students recognized the need for developed decision and judgement making. In Piaget's sense, this means that they can take into consideration the perspectives of others, to coordinate their own as well as viewpoints of others in order to make reasonable decisions; in other words, it could be said that they sense the lack of reflexive autonomy better than their professors, i.e. they feel greater need to make a choice based on the awareness of one's own ideas, experiments, observations, interests and values, which has already been found by other studies as significant elements of manifestation of reflexive autonomy (Koestner \& Loiser, 1996, as cited by Lalic-Vucetic et.al., 2009). In the interpretation of this finding, another statement could be born in mind, i.e. the students judged that their professors did not pay enough attention to their intellectual autonomy, because they did not sufficiently use didactic strategies and methods for the encouragement of strategies which are the foundation of scientific critical thinking, encouraging use of independence in thinking and decision making, since, as it has been judged by students, the teachers do not give them enough opportunities to learn how to solve problems and make decisions within broader range of choices and in discussions and other techniques of autonomy encouragement (Gronlick \& Ryan, as cited by Lalic-Vucetic et al., 2009).

Achieved competencies with higher average values are mostly those that are significant for intellectual functioning, but they are not directly related to what explains intellectual autonomy, i.e. the knowledge of basic notions, the understanding of facts, and the giving explanations of events.

It is interesting to note that standard deviations are smaller for the evaluation of the high prominence of competencies than for the evaluation of the low prominence of those that they consider to be more needed that is more deficient. Regardless, it would be difficult to find the answer to this question in the current research; it should be a subject of another observation, while free interpretation of this finding could be in the direction of the reflection on the abilities of gifted students to assess their advantages well. At the same time, the correspondence at the level of competences assessment are higher, since the competencies are recognized, and the opposite, there is higher standard deviation with underdeveloped competencies, especially in regard to research work; this could be an indicator of insecure, and even incorrect evaluations due 
to insufficient participation in these types of activities, i.e. due to the lack of knowledge of the essence and the level of these competencies, which can imply sincerity in providing responses, but it can also mean that students have different learning styles, manifested in these differences.

\section{Table 1. Achieved competencies}

Number of participants (N), Means (M) and standard deviations (SD) of the acquired competencies

\begin{tabular}{llll}
\hline & N & M & SD \\
\hline Knowledge of terms (acquired competencies) & 146 & 3.91 & 0.902 \\
Use of graphic data presentation & 145 & 3.48 & 1.208 \\
Knowledge of basic concepts & 146 & 4.24 & 0.897 \\
Understanding of facts & 146 & 4.21 & 0.830 \\
Explaining events & 145 & 4.03 & 0.837 \\
Usage of terms in new situations & 146 & 3.87 & 1.052 \\
Demonstration of the correct implementation of methods & 145 & 3.63 & 1.118 \\
Demonstration of knowledge usage & 146 & 3.66 & 1.039 \\
Finding mistakes in memory, decisions, and thinking & 146 & 3.71 & 0.982 \\
Realizing the connection between cause and effect & 146 & 3.92 & 0.976 \\
Finding hidden connections between data & 143 & 3.48 & 1.106 \\
Writing creative compositions & 146 & 3.34 & 1.283 \\
Making an experiment plan & 146 & 2.84 & 1.365 \\
Establishing findings & 146 & 3.53 & 1.140 \\
Product valuing & 146 & 3.54 & 0.976 \\
Assessment & 145 & 3.85 & 0.877 \\
Singling out the main points & 146 & 4.18 & 0.973 \\
Singling out the main ideas & 146 & 4.18 & 0.922 \\
Summarizing & 146 & 4.16 & 0.945 \\
Text interpretation & 146 & 4.32 & 0.805 \\
Creating content structure & 146 & 3.95 & 0.866 \\
Making subtitles & 146 & 4.10 & 0.949 \\
Finding analogies & 146 & 3.68 & 1.144 \\
Application of ideas from a given text & 146 & 3.64 & 1.036 \\
Asking questions connected to the text & 145 & 4.00 & 0.965 \\
Formation of a concept web & 146 & 3.68 & 1.057 \\
Prominence of logical thinking & 145 & 3.90 & 1.039 \\
Prominence of sceptical thinking & 145 & 3.42 & 1.128 \\
Independent thinking & 146 & 4.14 & 0.894 \\
Natural science thinking & 145 & 3.48 & 1.173 \\
Systematic thinking & 145 & 3.78 & 1.031 \\
Prominence of networked thinking & 146 & 3.56 & 1.037 \\
Prominence of self-reflective thinking & 145 & 3.53 & 1.149 \\
Valid N & 135 & & \\
\hline
\end{tabular}

Chart 3. Realized competences 


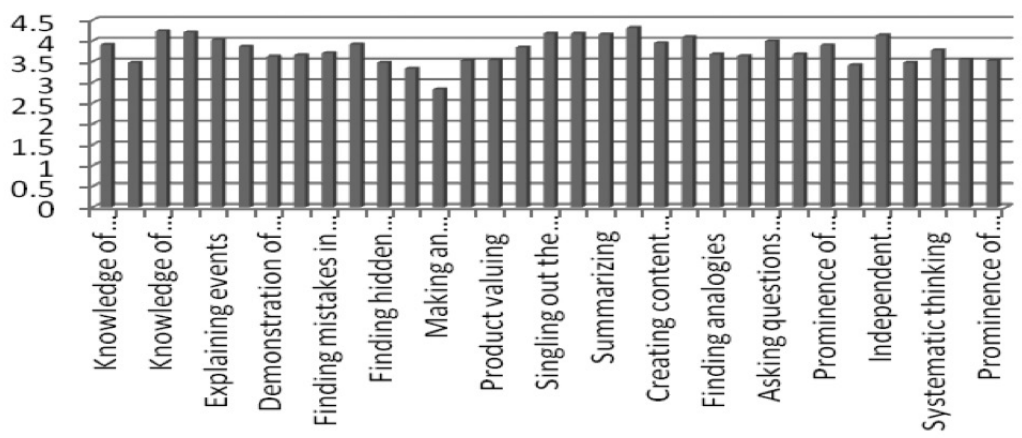

The question that is relevant for the research refers to the relationship between the achieved competencies and the methods and procedures with which the students were directed to searching for sources of information on the Internet and in the designated readings to which they also gain access via the internet. Noticeable are the important connections of the dependent variable: Search for information (pronounced), and the students' assessment of the competency development level. Therefore, we could say that gifted students' assess a great value to searching for information on the Internet if they are engaged in the following: demonstrating the implementation of methods, demonstrating knowledge use, noticing mistakes in memory, judging, thinking, realizing the connection between cause and effect, writing creative compositions, summarizing, natural science thinking, prominence of networked thinking, application of ideas from a given text, formation of a concept web, prominence of sceptical thinking, prominence of self-reflective thinking.

Previous findings are in accordance with the standpoints expressed by Taisir Subhia Yamin (General Director of the International Centre for Innovation in Education (ICIE), who, in his text "New Horizons for Talented Education in Digital World" (2014), emphasizes the need to use the potentials offered by the digital world in education of the gifted within an educational system, implying the optimized use of technologies and computerized platforms and other systems in education settings. The findings we are commenting on here are in favour of the viewpoints of that author, according to whom it will not be long before the gifted require an increasing number of programs including telementoring, online groupings, e-learning and virtual learning settings; teaching for productive thinking and problem solving, global networks and forums for students, teachers and scientists. Previous findings confirm that students greatly appreciate the possibilities to exchange knowledge, experiences, interests, values and outcomes and advantages. They consider it normal to introduce methods 
leading to the introduction of more efficient practices through the use of ICT. The current findings are in accordance with previous statements, implying that the gifted have realized the importance of digital world and that they assess that ICT contributes to competences that could be classified within the set of intellectual autonomy abilities. This is further in favour of the standpoint that gifted students recognize the limits of the application of innovative potentials of contemporary methods in higher education teaching (project method, discourse method, didactic instructions convening with cognitive style dimensions, putting the special accent on the use of ICT in these and other methods), from the angle of metacognitive abilities development, leading to a conclusion that metacognitive approaches to learning in the case of gifted students correlate with ICT in the process of independent learning and research procedures. This is particularly evident in the relations between the project method and the discourse method, which fit well in the classical teaching system, while the use of the potentials of digital world by gifted students encourages intrinsic motivation, mostly because they can research independently finding pieces of information and networking with students worldwide, consulting with them and searching for new sources. Nowadays, students have mastered English, German and other languages, so that they overcome space and language barriers, accessing world libraries, communicating with students and others interested in the same problem issue, thus learning with higher level of motivation, manifesting high level of flexibility, creativity, risk-taking readiness and persistence in search for arguments in favour of ideas they advocate. The importance of the digital world thus contributes to the development of the intellectual autonomy of gifted students, bearing in mind that they have opportunities for discussions during lectures, practical classes, and seminars, since they can prepare original argumentations for new angles of the given issue, or to raise new questions. In other words, boundaries have been erased, and the ideal of participatory epistemology in learning approaches has become possible, opening the way to autonomy and self-regulated learning. Furthermore, there are currently numerous and various models offering possibilities for e-learning of the gifted. One of them is already well-known: the Renzulli Learning System, which is the first integrated system introduced in the educational system in the USA. It is used for the identification and development of the gifted and offers easily accessible learning contents of high quality. It is suitable for the abilities, interests, learning styles and expression styles of the gifted, which can help teachers to ensure packages for productive thinking skills and appropriate differentiations of activities for learners of all levels of achievements and abilities (Taisir Subhia Yamin, 2014). 


\section{Conclusions}

Previous findings confirm the principles of critical thinking discussed in the theoretical part of this paper. The aforementioned results are in accordance with Facione's view (Facione, 1990), emphasizing the step forward from critical thinking to the critical thinker. In their expectations, students singled out a greater need for teaching methods and didactic instruction, which encourages curiosity, being well-informed, open-minded, flexible, confronting personal prejudices, carefully making decisions, the will for re-evaluation, clarity in asking questions, organization in complex matters, being diligent in the search for relevant information, responsible for the grouping of criteria, focused on the task, planning experiments, globalizing of results, product valuing, the application of ideas, prominence of sceptical thinking, natural science thinking, the prominence of networked thinking and the prominence of self-reflection in thinking. All of this indicates that the gifted feel the importance of cognitive competencies and affective dispositions; therefore, they understand the importance of procedural and dispositional side of critical thinking. It could be further concluded that higher education teachers in their work with the gifted should take these findings into consideration, employing in their work with students strategies, methods and instructions encouraging not only critical thinking (thinking, providing arguments, getting information), but also what could be classified as the competencies, attitudes and approaches of intellectually autonomous critically-thinking individual.

\section{References}

European Council. (2008). Retrieved from www.jointquality.org

Facione, P. A. (1990). Critical thinking: A statement of expert consensus for purposes of educational assessment and instruction. Millbrae, CA: The California Academic Press.

Gojkov, G. (2007). Metapedagoške rasprave [Meta-pedagogic discussions]. Novi Sad: Savez pedagoških društava Vojvodine.

Gojkov, G. (2013). Fragmenti visokoškolske didaktike [Fragments of higher education didactics].

Vršac: VŠSSV,'M. Palov".

Gojkov, G. (2014). Importance of the Digital Age for the Development of Intellectual Autonomy of Gifted Students - ECHA CONFERENCE NEWS 2014, Re:thinking giftedness:giftedness in the digital age, 17 - 20 September 2014, Issue 2, July 2014, p.7. Retrieved from www.echa2014.info Gojkov, G., \& Stojanović, A. (2011). Participativna epistemologija u didaktici [Participatory epistemology in didactics]. Vršac: VŠSSV "M. Palov".

Gojkov, G., \& Stojanović, A. (2012). Funkcija znanja i moralnosti. Vršac: VŠV “M. Palov". 
Heyman, G. D. (2008). Children's critical thinking when learning from others. Current Directions in Psychological Science, 17(5), 344-347.

Kruse, O. (2010). Kritisches Denken im Zeichen Bolognas: Rhetorik und Realität. In U. Eberhardt (Ed.), Neue Impulse in der Hochschuldidaktik. Sprach- und Literaturwissenschaften (pp. 45-82). Berlin: Verlag für Sozialwissenschaften.

Lalić-Vučetić, N., Đerić, I., \& Đević, R. (2009). Učenička autonomija i interpersonalni stil nastavnika u teoriji samodeterminacije [Student Autonomy and Interpersonal Style of Teachers in the Theory of Self-Determination]. In Zbornik Instituta za pedagoška istraživanja br. 2. Beograd: Institut za pedagoška istraživanja.

Taisir Subhi Yamin (2014). ECHA New Horizons for Gifted Education in the digital WorldCONFERENCE NEWS 2014, Re:thinking giftedness:giftedness in the digital age, 17 - 20 September 2014, Ljubljana, Issue 2, July 2014, p. 6. Retrieved from www.echa2014.info

Willingham, D. T. (2007). Can critical thinking be taught? American Educator, The Department of Psychology at the University of Virginia. Retrieved 27. 10. 2014 from www.jointquality.org

\section{Biographical note}

Grozdanka GojKov is a full professor of Methodology of pedagogic research and Didactics as well as an author of many monographic studies, textbooks and handbooks in this field. She participated in many research projects and was a visiting professor at lots of universities. She is a honorable member of the Association for the Gifted in Macedonia, Professor emeritus at the University of Banatul in Timisoara, member of ECHA and other organizations and editorial boards in Serbia and abroad, a regular member of C.E.A.S.A. in Paris, SAO in Belgrad and Honorable Doctor of Science at Universities „Aurel Vlajku" (Arad) and "SV. Kliment Ohridski" (Bitola).

Aleksandar Stojanovic obtained a PhD degree in pedagogical sciences at Pthe hilosophical Faculty, Novi Sad University. He works at the Teacher Training Faculty in Belgrade and the Preschool Teacher Training College "Mihailo Palov" in Vrsac. He became an asociate professor of Didactics in 2008 in Belgrade. He is teaching Didactics, General Pedagogy, Pedagogic Research Methodology, Preschool Pedagogy, and Mathematics Teaching Methodology at Preschool Age. He is a manager of the publishing activity of the Preschool Teacher Training College in Vrsac. Since 2009 he has bee a member of the Education Council of the Province of Vojvodina. 
Aleksandra Gojkov - Rajic obtained 2011 her PhD degree at the Department for German Language and Literature at the Philosophical Faculty in Novi Sad. She teaches german language at the Teacher Training Faculty in Belgrade and the Preschool Teacher Training College "Mihailo Palov" in Vrsac. She has published 6 books and around 20 professional papers from the field of German literature, cultural connections and foreign language teaching methodology, as well as a number of translations, among which the two books written by G. Grass should be emphasized. 